\title{
Methodological quality and implications for practice of systematic Cochrane reviews in pediatric oral health: a critical assessment
}

\author{
Violaine Smaïl-Faugeron ${ }^{1,2,3^{*}}$, Hélène Fron-Chabouis ${ }^{3,4}$ and Frédéric Courson ${ }^{2,3}$
}

\begin{abstract}
Background: To ensure evidence-based decision-making in pediatric oral health, Cochrane systematic reviews that address topics pertinent to this field are necessary. We aimed to identify all systematic reviews of paediatric dentistry and oral health by the Cochrane Oral Health Group (COHG), summarize their characteristics and assess their methodological quality. Our second objective was to assess implications for practice in the review conclusions and provide an overview of clinical implications about the usefulness of paediatric oral health interventions in practice.

Methods: We conducted a methodological survey including all paediatric dentistry reviews from the COHG. We extracted data on characteristics of included reviews, then assessed the methodological quality using a validated 11-item quality assessment tool (AMSTAR). Finally, we coded each review to indicate whether its authors concluded that an intervention should be implemented in practice, was not supported or was refuted by the evidence, or should be used only in research (inconclusive evidence).

Results: We selected 37 reviews; most concerned the prevention of caries. The methodological quality was high, except for the assessment of reporting bias. In 7 reviews (19\%), the research showed that benefits outweighed harms; in 1, the experimental intervention was found ineffective; and in 29 (78\%), evidence was insufficient to assess benefits and harms. In the 7 reviews, topical fluoride treatments (with toothpaste, gel or varnish) were found effective for permanent and deciduous teeth in children and adolescents, and sealants for occlusal tooth surfaces of permanent molars.
\end{abstract}

Conclusions: Cochrane reviews of paediatric dentistry were of high quality. They provided strong evidence that topical fluoride treatments and sealants are effective for children and adolescents and thus should be implemented in practice. However, a substantial number of reviews yielded inconclusive evidence.

Keywords: Systematic reviews, Cochrane collaboration, Children oral health, Implication for practice, Caries prevention

\section{Background}

Evidence-based dentistry has contributed substantially to improving the quality of oral health in general and in the paediatric population in particular. Systematic reviews of randomized controlled trials (RCTs) are considered the highest standard in evidence-based healthcare available to clinicians to guide clinical practice. The

\footnotetext{
* Correspondence: violaine.smail-faugeron@parisdescartes.fr

${ }^{1}$ Institut National de la Santé et de la Recherche Médicale, UMR S 872,

Equipe 22, Centre de Recherche des Cordeliers, Paris, France

${ }^{2}$ Assistance Publique-Hôpitaux de Paris, Hôpital Bretonneau, Service d'Odontologie,

Paris, France

Full list of author information is available at the end of the article
}

Cochrane Collaboration is the world's largest producer of systematic reviews of primary research in human health care and health policy [1]. The Cochrane Oral Health Group (COHG) is one of 50 review groups within the Cochrane Collaboration.

High methodological quality is necessary for valid interpretation and application of systematic review findings $[2,3]$. Moreover, systematic reviews can be a source of knowledge for healthcare practice, provided that they give conclusive evidence that interventions are effective, ineffective or harmful. To our knowledge, no study has assessed the methodological quality and implications for 
practice of Cochrane systematic reviews of paediatric oral health.

We aimed to identify all existing systematic reviews of the COHG related to paediatric dentistry and oral health and to summarize the most relevant characteristics of the reviews. Our second objective was to evaluate the methodological quality of the systematic reviews using A Measurement Tool to Assess Systematic Reviews (AMSTAR), a validated 11-item quality assessment tool. Finally, we aimed to assess the implications for practice in the review conclusions and provide an overview of clinical implications about the usefulness of paediatric oral health interventions in practice.

\section{Methods}

We conducted a methodological survey including all paediatric reviews indexed in the Dentistry and Oral Health category of the COHG reviews. We extracted data on characteristics of included Cochrane reviews, then assessed the methodological quality using the AMSTAR checklist. Finally, we examined the review conclusions to assess whether the experimental intervention was conclusive, ineffective, harmful or contained inconclusive evidence.

\section{Criteria for considering systematic reviews}

Eligible systematic reviews were of paediatric dentistry and oral health produced by the COHG. In the first step, we selected systematic reviews if the authors clearly reported participants as "children" or "adolescents" in the title and objectives. If this was not clear, we systematically examined the full text of selected articles to determine whether authors defined an upper age limit as selection criteria or whether the maximum age of included patients was $\leq 18$ years old. We selected updates of systematic reviews rather than initial versions. We excluded systematic reviews that included at least one RCT of adults and reviews that did not mention the age of participants.

\section{Search methods for systematic reviews}

We identified eligible Cochrane systematic reviews indexed in the Dentistry and Oral Health category of the COHG at www.thecochranelibrary.com. The last search was conducted in November 2013. Two authors independently and in duplicate screened all full-text reports. Any disagreements were resolved by discussion.

\section{Data extraction}

\section{Characteristics of included Cochrane systematic reviews}

Two reviewers extracted data independently and in duplicate, with discrepancies resolved by discussion. For each systematic review, we recorded the publication year, the country, the topic, the participants and the primary outcomes. For each meta-analysis of primary outcomes, we recorded the experimental intervention, the comparator, the number of RCTs examined, the number of participants, and the relative effect (treatment effect measure and combined estimate [ $95 \%$ confidence interval]).

\section{Assessment of methodological quality of Cochrane systematic reviews}

Two reviewers independently and in duplicate evaluated the methodological quality of systematic reviews using the AMSTAR checklist, a measurement tool of 11 items $[4,5]$. Disagreements were resolved with a third author. We did not use the PRISMA checklist because it is not intended to be a quality assessment tool as compared with the AMSTAR, which is a reliable and valid measurement tool to assess the methodological quality of systematic reviews $[5,6]$. The following characteristics were assessed: a priori design, study selection and data extraction, literature search, status of publication, characteristics of the included and excluded studies, scientific quality of the included studies, methods used to combine the findings of studies, publication bias and conflict of interest.

\section{Assessment of the implications for practice in conclusions sections of Cochrane systematic reviews}

Two reviewers independently examined the implicationsfor-practice paragraph in the conclusions sections of all selected systematic reviews. Disagreements were resolved by a third author. For each review, we assessed whether the experimental intervention should be implemented in practice (ie, conclusive evidence that the intervention was effective and not harmful), was ineffective and should not be used in practice, was harmful and should not be used in practice, or should be used only in research (ie, the evidence identified was inconclusive; that is, the intervention could be beneficial or harmful) $[7,8]$. The experimental intervention was considered ineffective if the evidence showed that it was ineffective for all primary outcomes, harmful if the evidence showed it was harmful for at least one adverse event, to be used in research only if the evidence was inconclusive for at least one primary outcome, or should be implemented in practice if the evidence showed that it was effective for all primary outcomes and not harmful, with no adverse events.

\section{Results}

\section{Eligible Cochrane systematic reviews}

The search yielded 278 Cochrane systematic reviews that specifically addressed dentistry and oral health issues. After 7 duplicates were removed, we finally included 37 systematic reviews focused on paediatric oral health [9-45]. 
Characteristics of included Cochrane systematic reviews The median year of publication was 2008 (range 20022013) (Table 1). Most systematic reviews (57\%) were performed in the United Kingdom. The reviews mainly concerned interventions for the prevention of dental caries $(n=16)$, orthodontic treatment and oral surgery $(\mathrm{n}=4$ for each domain), treatment of dental caries $(\mathrm{n}=3)$ and behavior management $(\mathrm{n}=2)$. Details are given in Additional file 1: Table S1.

\section{Comparisons of primary outcomes}

In 30 reviews, no meta-analysis was performed for primary outcomes in 65 comparisons: for 9 comparisons,

\section{Table 1 Characteristics of included systematic reviews}

\begin{tabular}{lc}
\hline Characteristics & No of reviews (\%) \\
\cline { 2 - 2 } & $\mathbf{n}=\mathbf{3 7}$ \\
\hline Publication year & \\
$2002-2004$ & $9(24 \%)$ \\
$2005-2007$ & $8(22 \%)$ \\
$2008-2010$ & $8(22 \%)$ \\
$2011-2013$ & $12(32 \%)$ \\
Country & \\
United Kingdom & $21(57 \%)$ \\
Brazil & $3(8 \%)$ \\
Germany & $2(5 \%)$ \\
China & $2(5 \%)$ \\
Ireland & $2(5 \%)$ \\
Finland & $2(5 \%)$ \\
Oman & $1(3 \%)$ \\
Syrian Arab Republic & $1(3 \%)$ \\
South Africa & $1(3 \%)$ \\
France & $1(3 \%)$ \\
The Netherlands & $1(3 \%)$ \\
Trepic & $1(3 \%)$ \\
Prevention of dental caries & $1(3 \%)$ \\
Orthodontic treatment & $1(3 \%)$ \\
Oral surgery & $1(3 \%)$ \\
Breatment of dental caries & $1(10 \%)$ \\
Treatmentment & $1(3 \%)$ \\
\hline
\end{tabular}

no RCT existed for the primary outcomes; for 53 comparisons, only $1 \mathrm{RCT}$ existed for the primary outcomes; and for 3 comparisons (2, 3, and 3 RCTs), no metaanalysis was performed for the primary outcomes. In 15 reviews, 65 meta-analyses were performed for primary outcomes (at least 2 RCTs included). Among the 65 meta-analyses, the median number of RCTs per metaanalysis was 3 [Q1-Q3 2-6, min-max 2-133] and the median number of patients per meta-analysis was 360 [Q1-Q3 182-1,673, min-max 50-65,179]. The number of meta-analyses with continuous outcomes was 61 (94\%). Details are given in Additional file 2: Table S2.

\section{Methodological quality of Cochrane systematic reviews}

The overall quality of the selected reviews was high according to the AMSTAR checklist. In all reviews, the reporting of 8 of the 11 items was adequate (Figure 1). The weakest area was failure to report the likelihood of publication bias, in 14 reviews (38\%), which did not assess publication bias [11-13,17,19,20,24-26,34,35,38,42,43]. One review did not use "grey" literature as an inclusion criterion [34] and in another, the methods used to combine the findings of studies were inappropriate [38].

\section{Implications for practice in Cochrane systematic reviews} For the 37 systematic reviews, 7 (19\%) concluded that specific interventions should be implemented in practice (ie, interventions for which research showed that benefits outweighed harms), and 1 concluded that specific interventions should not be used in practice because of ineffectiveness (Table 2). All experimental interventions that had been shown to be effective involved prevention of dental caries. Research evidence supported the effectiveness of topical fluoride treatments (with toothpaste, gel or varnish) for permanent and deciduous teeth in children and adolescents, and sealants for occlusal tooth surfaces of permanent molars. We did not identify any intervention for which research showed that harms outweighed benefits. However, for 29 reviews (78\%), the evidence was inconclusive because it was limited (see Additional file 3: Table S3).

\section{Discussion}

Our study shows that the number of Cochrane systematic reviews in paediatric dentistry and oral health has increased during the last few years. This situation should improve the basis for clinical decision-making because systematic reviews are considered essential sources of evidence for guideline development [46]. The methodological quality of most of our reviews was high, corresponding to the high quality standards of the Cochrane Collaboration. Nevertheless, the likelihood of publication bias was not frequently assessed. This is an important 


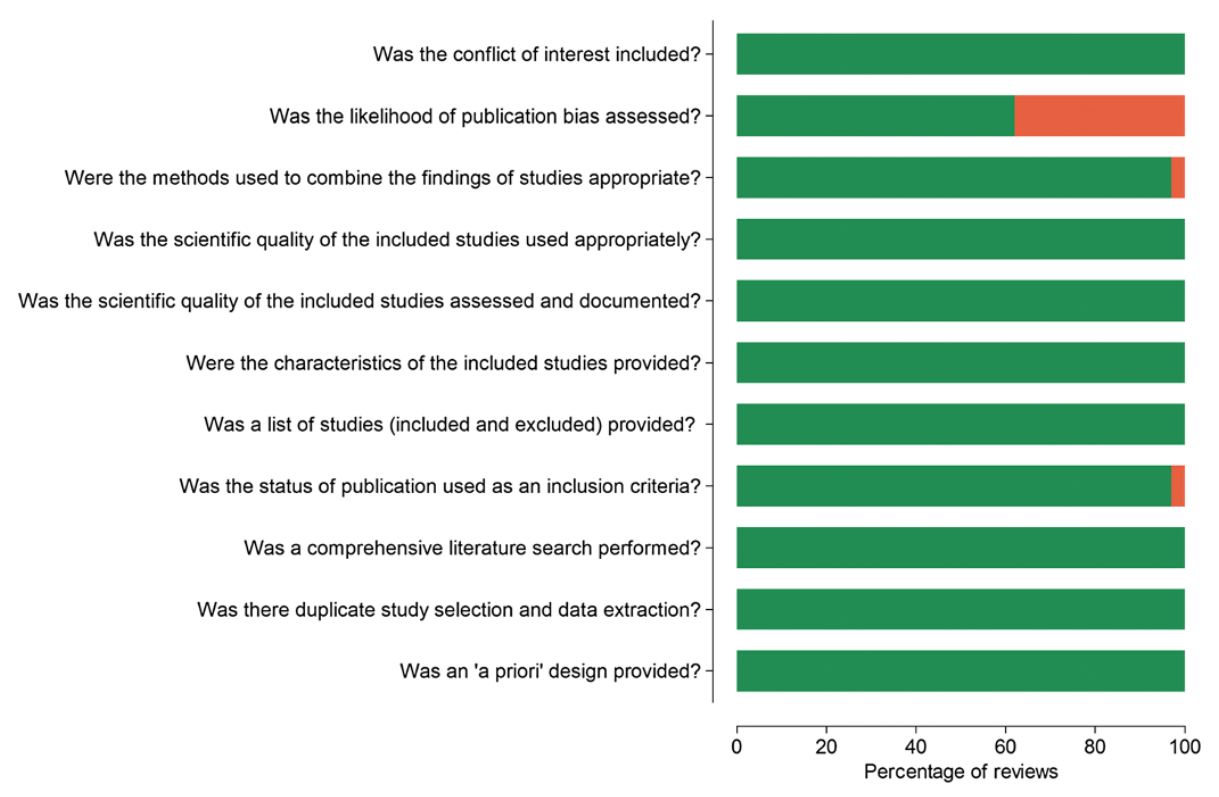

Figure 1 Assessment of methodological quality of included studies using AMSTAR.

factor to take into account in the conduct of a metaanalysis and in the interpretation of results [47].

Cochrane reviews should not define recommendations for practice because this requires assumptions about the relative importance of benefits and harms of an intervention and judgements that are beyond the scope of a systematic review. However, Cochrane review authors always propose implications for practice. Our study demonstrated that most of the reviews (43\%) and all interventions supported by research evidence focused on the prevention of dental caries. For children and adolescents, topical fluoride treatments (with toothpaste, gel or varnish) were found effective for permanent and deciduous teeth and sealants for occlusal tooth surfaces of permanent molars. The predominance of this topic seems justified because it is the most important from a public health policy viewpoint. Early childhood caries is the most frequent chronic disease affecting young children and is 5 times more common than asthma [48]. The selected reviews also concerned orthodontic treatment and oral surgery. However, for clinicians, several secondary research gaps are the management of oro-dental trauma or conservative treatments. Actually, the latter involve materials that may be harmful because of some toxicity [49,50].

Many of our reviews (78\%) produced inconclusive evidence. The most common reasons for failure to provide reliable information to guide clinical decisions are the small numbers of RCTs and patients per meta-analysis. According to a cross-sectional descriptive analysis about characteristics of meta-analyses in the Cochrane Database of Systematic Reviews, the median number of RCTs included in meta-analyses was 3 (Q1-Q3 2-6) and the median number of patients was 91 (Q1-Q3 44-210) [51]. Our findings are consistent with these figures and emphasize that more high-quality primary research may be frequently needed to reach conclusiveness. However, none of the selected reviews was empty; that is, randomized evidence always existed and was included in the review, even when inconclusive. Another explanation for the inconclusiveness may be the inability to perform data synthesis. Diversity in outcomes measured across RCTs within a review may substantially limit the ability to perform meta-analyses and may explain the lack of recommendations [52,53]. Many meta-analyses frequently exclude a large number of RCTs because outcomes are too different between studies [54]. The standardization of outcomes was initiated by the OMERACT group [55] and is expanding with the COMET Initiative [56]. In the field of dentistry, some studies have defined core outcome sets to help solve this problem, such as in implantology [57-60] and for the evaluation of pulp treatments in primary teeth [61]. Finally, all systematic reviews should be considered as informative because they may allow for identifying well-informed uncertainties about the effects of treatments [62,63].

Previous methodological surveys assessed the conduct quality of systematic reviews in the field of dentistry [64-66]. In a study of 109 systematic reviews published in major orthodontic journals, 26 were published in the Cochrane Database of Systematic Reviews. In all, 21\% of the selected reviews satisfied 9 or more of the 11 AMSTAR criteria $[64,65]$. However, to our best knowledge, no methodological survey concerned specifically pediatric oral health. 
Table 2 Characteristics of systematic reviews with experimental interventions that had been found effective and should be implemented in practice

\begin{tabular}{|c|c|c|c|c|c|c|c|}
\hline Review & Participants & Intervention & Comparator & Outcome & \# RCTs & \# pts & $\begin{array}{c}\text { Relative } \\
\text { effect }[95 \% \mathrm{Cl}]\end{array}$ \\
\hline 1830 & $\begin{array}{l}\text { Permanent teeth in children } \\
\text { and adolescents }\end{array}$ & $\begin{array}{l}\text { Resin-based sealant } \\
\text { applications on occlusal } \\
\text { tooth surfaces of } \\
\text { permanent molars }\end{array}$ & $\begin{array}{l}\text { No sealant } \\
\text { application }\end{array}$ & $\begin{array}{l}\text { Dentine caries in } \\
\text { permanent molars } \\
\text { Follow-up: } 2 \text { yr }\end{array}$ & 6 & 1,066 & $\begin{array}{c}\text { OR } 0.12 \\
{[0.07 ; 0.19]}\end{array}$ \\
\hline 2278 & $\begin{array}{l}\text { Permanent teeth in children } \\
\text { and adolescents }\end{array}$ & Fluoride toothpaste & Placebo & $\begin{array}{l}\mathrm{D}(\mathrm{M}) \text { FS increment - } \\
\text { nearest to } 3 \mathrm{yr}\end{array}$ & 70 & 42,300 & $\begin{array}{l}\text { SMD }-0.31 \\
{[-0.35 ;-0.27]}\end{array}$ \\
\hline 2278 & $\begin{array}{l}\text { Permanent teeth in children } \\
\text { and adolescents }\end{array}$ & Fluoride toothpaste & Placebo & $\begin{array}{l}\mathrm{D}(\mathrm{M}) \mathrm{FT} \text { increment- } \\
\text { nearest to } 3 \mathrm{yr}\end{array}$ & 53 & 32,371 & $\begin{array}{l}\text { SMD }-0.28 \\
{[-0.33 ;-0.23]}\end{array}$ \\
\hline 2279 & $\begin{array}{l}\text { Permanent and deciduous teeth } \\
\text { in children and adolescents }\end{array}$ & Fluoride varnishes & $\begin{array}{l}\text { Placebo/no } \\
\text { treatment }\end{array}$ & $\begin{array}{l}\mathrm{D}(\mathrm{M}) \mathrm{FS} \text { increment - } \\
\text { nearest to } 3 \mathrm{yr}\end{array}$ & 7 & 2,278 & $\begin{array}{l}\text { SMD }-0.46 \\
{[-0.65 ;-0.26]}\end{array}$ \\
\hline 2280 & $\begin{array}{l}\text { Permanent and deciduous teeth } \\
\text { in children and adolescents }\end{array}$ & Fluoride gels & Placebo & $\begin{array}{l}\mathrm{D}(\mathrm{M}) \mathrm{FS} \text { increment - } \\
\text { nearest to } 3 \mathrm{yr}\end{array}$ & 14 & 4,492 & $\begin{array}{l}\text { SMD }-0.20 \\
{[-0.29 ;-0.10]}\end{array}$ \\
\hline 2280 & $\begin{array}{l}\text { Permanent and deciduous teeth } \\
\text { in children and adolescents }\end{array}$ & Fluoride gels & No treatment & $\begin{array}{l}\mathrm{D}(\mathrm{M}) \mathrm{FS} \text { increment - } \\
\text { nearest to } 3 \mathrm{yr}\end{array}$ & 9 & 2,677 & $\begin{array}{l}\text { SMD }-0.46 \\
{[-0.65 ;-0.27]}\end{array}$ \\
\hline 2280 & $\begin{array}{l}\text { Permanent and deciduous teeth } \\
\text { in children and adolescents }\end{array}$ & Fluoride gels & Placebo & $\begin{array}{l}\mathrm{D}(\mathrm{M}) \mathrm{FT} \text { increment - } \\
\text { nearest to } 3 \text { years }\end{array}$ & 4 & 1,525 & $\begin{array}{l}\text { SMD }-0.19 \\
{[-0.29 ;-0.09]}\end{array}$ \\
\hline 2280 & $\begin{array}{l}\text { Permanent and deciduous teeth } \\
\text { in children and adolescents }\end{array}$ & Fluoride gels & No treatment & $\begin{array}{l}\mathrm{D}(\mathrm{M}) \mathrm{FT} \text { increment - } \\
\text { nearest to } 3 \text { years }\end{array}$ & 6 & 1,673 & $\begin{array}{l}\text { SMD }-0.73 \\
{[-1.13 ;-0.32]}\end{array}$ \\
\hline 2284 & $\begin{array}{l}\text { Permanent and deciduous teeth } \\
\text { in children and adolescents }\end{array}$ & Fluoride mouthrinses & $\begin{array}{l}\text { Placebo/no } \\
\text { treatment }\end{array}$ & $\begin{array}{l}D(M) F S \text { increment - } \\
\text { nearest to } 3 \text { years }\end{array}$ & 34 & 14,663 & $\begin{array}{l}\text { SMD }-0.30 \\
{[-0.36 ;-0.24]}\end{array}$ \\
\hline 2284 & $\begin{array}{l}\text { Permanent and deciduous teeth } \\
\text { in children and adolescents }\end{array}$ & Fluoride mouthrinses & $\begin{array}{l}\text { Placebo/no } \\
\text { treatment }\end{array}$ & $\begin{array}{l}\mathrm{D}(\mathrm{M}) \mathrm{FT} \text { increment - } \\
\text { nearest to } 3 \text { years }\end{array}$ & 13 & 5,105 & $\begin{array}{l}\text { SMD }-0.28 \\
{[-0.37 ;-0.20]}\end{array}$ \\
\hline 2782 & $\begin{array}{l}\text { Permanent and deciduous teeth } \\
\text { in children and adolescents }\end{array}$ & Topical fluoride & $\begin{array}{l}\text { Placebo/no } \\
\text { treatment }\end{array}$ & $\begin{array}{l}\mathrm{D}(\mathrm{M}) \mathrm{FS} \text { increment - } \\
\text { nearest to } 3 \text { years }\end{array}$ & 133 & 65,179 & $\begin{array}{c}\text { PF } 0.26 \\
{[0.23 ; 0.29]}\end{array}$ \\
\hline 2782 & $\begin{array}{l}\text { Permanent and deciduous teeth } \\
\text { in children and adolescents }\end{array}$ & Topical fluoride & $\begin{array}{l}\text { Placebo/no } \\
\text { treatment }\end{array}$ & $\begin{array}{l}\mathrm{D}(\mathrm{M}) \mathrm{FT} \text { increment - } \\
\text { nearest to } 3 \mathrm{yr}\end{array}$ & 79 & 41,391 & $\begin{array}{l}\text { PF } 0.26 \\
{[0.21 ; 0.30]}\end{array}$ \\
\hline 2782 & $\begin{array}{l}\text { Permanent and deciduous teeth } \\
\text { in children and adolescents }\end{array}$ & Topical fluoride & $\begin{array}{l}\text { Placebo/no } \\
\text { treatment }\end{array}$ & $\begin{array}{l}\mathrm{d}(\mathrm{e}) \text { fs increment - } \\
\text { nearest to } 3 \mathrm{yr}\end{array}$ & 5 & 1,685 & $\begin{array}{c}\text { PF } 0.33 \\
{[0.22 ; 0.44]}\end{array}$ \\
\hline 7868 & $\begin{array}{l}\text { General population of children } \\
\text { and adolescents }\end{array}$ & Fluoride toothpaste & $\begin{array}{l}\text { Placebo or other } \\
\text { fluoride toothpaste }\end{array}$ & $\begin{array}{l}\mathrm{D}(\mathrm{M}) \mathrm{FS} \text { increment - } \\
\text { nearest to } 3 \mathrm{yr}\end{array}$ & 74 & $\begin{array}{l}\text { Not } \\
\text { clear }\end{array}$ & $\begin{array}{c}\text { PF } 19.79 \\
{[16.72 ; 22.87]}\end{array}$ \\
\hline 7868 & $\begin{array}{l}\text { General population of children } \\
\text { and adolescents }\end{array}$ & Fluoride toothpaste & $\begin{array}{l}\text { Placebo or other } \\
\text { fluoride toothpaste }\end{array}$ & $\begin{array}{l}\mathrm{D}(\mathrm{M}) \mathrm{FT} \text { increment - } \\
\text { nearest to } 3 \mathrm{yr}\end{array}$ & 54 & $\begin{array}{l}\text { Not } \\
\text { clear }\end{array}$ & $\begin{array}{c}\text { PF 21.1 } \\
{[16.86 ; 25.47]}\end{array}$ \\
\hline 7868 & $\begin{array}{l}\text { General population of children } \\
\text { and adolescents }\end{array}$ & Fluoride toothpaste & $\begin{array}{l}\text { Placebo or other } \\
\text { fluoride toothpaste }\end{array}$ & $\begin{array}{l}D(M) F S \text { increment } \\
\text { nearest to } 3 \mathrm{yr}\end{array}$ & 74 & $\begin{array}{l}\text { Not } \\
\text { clear }\end{array}$ & $\begin{array}{l}\text { SMD }-0.24 \\
{[-0.27 ;-0.20]}\end{array}$ \\
\hline 7868 & $\begin{array}{l}\text { General population of children } \\
\text { and adolescents }\end{array}$ & Fluoride toothpaste & $\begin{array}{l}\text { Placebo or other } \\
\text { fluoride toothpaste }\end{array}$ & $\begin{array}{l}\mathrm{D}(\mathrm{M}) \mathrm{FT} \text { increment - } \\
\text { nearest to } 3 \mathrm{yr}\end{array}$ & 54 & $\begin{array}{l}\text { Not } \\
\text { clear }\end{array}$ & $\begin{array}{l}\text { SMD }-0.24 \\
{[-0.28 ;-0.20]}\end{array}$ \\
\hline 7868 & $\begin{array}{l}\text { General population of children } \\
\text { and adolescents }\end{array}$ & Fluoride toothpaste & $\begin{array}{l}\text { Placebo or other } \\
\text { fluoride toothpaste }\end{array}$ & $\begin{array}{l}d(m) \text { fs increment - } \\
\text { nearest to } 3 \mathrm{yr}\end{array}$ & 3 & $\begin{array}{l}\text { Not } \\
\text { clear }\end{array}$ & $\begin{array}{c}\text { PF } 34.82 \\
{[25.68-43.96]}\end{array}$ \\
\hline 7868 & $\begin{array}{l}\text { General population of children } \\
\text { and adolescents }\end{array}$ & Fluoride toothpaste & $\begin{array}{l}\text { Placebo or other } \\
\text { fluoride toothpaste }\end{array}$ & $\begin{array}{l}d(m) f t \text { increment - } \\
\text { nearest to } 3 \mathrm{yr}\end{array}$ & 3 & $\begin{array}{l}\text { Not } \\
\text { clear }\end{array}$ & $\begin{array}{l}\text { PF 12.18 } \\
{[5.08-19.29]}\end{array}$ \\
\hline 7868 & $\begin{array}{l}\text { General population of children } \\
\text { and adolescents }\end{array}$ & Fluoride toothpaste & $\begin{array}{l}\text { Placebo or other } \\
\text { fluoride toothpaste }\end{array}$ & $\begin{array}{l}\text { Proportion developing } \\
\text { new caries (permanent) }\end{array}$ & 8 & $\begin{array}{l}\text { Not } \\
\text { clear }\end{array}$ & $\begin{array}{c}\text { RR 0.98 } \\
{[0.94-1.02]}\end{array}$ \\
\hline 7868 & $\begin{array}{l}\text { General population of children } \\
\text { and adolescents }\end{array}$ & Fluoride toothpaste & $\begin{array}{l}\text { Placebo or other } \\
\text { fluoride toothpaste }\end{array}$ & $\begin{array}{l}\text { Proportion developing } \\
\text { new caries (deciduous) }\end{array}$ & 3 & $\begin{array}{l}\text { Not } \\
\text { clear }\end{array}$ & $\begin{array}{c}\text { RR } 0.87 \\
{[0.81-0.93]}\end{array}$ \\
\hline
\end{tabular}

Yr, year; \#, number; pts, participants; 95\% Cl, 95\% confidence interval; RR: relative risk; OR: odds ratio; SMD: standardized mean difference; PF: prevented fraction = mean caries increment in controls - mean caries increment in the treated group/mean caries increment in controls. D(M)FS increment: caries increment on permanent tooth surfaces; D(M)FT increment: caries increment in permanent teeth; dmfs increment: caries increment on deciduous tooth surfaces; dmft increment: caries increment in deciduous teeth.

Our study has some limitations. Indeed, we considered only Cochrane systematic reviews in our study, but many non-Cochrane systematic reviews have also assessed interventions in the paediatric oral health field [67].
Nevertheless, Cochrane systematic reviews are the highest standard in evidence-based health care. Moreover, Cochrane reviews have a standard structure, which always includes implications for practice. Another potential limitation is that 
we assessed whether the experimental intervention should be used in practice, should not be used in practice or should be used only in research based on the Implications-for-practice section only and we did not critically judge the review evidence ourselves. However, Cochrane review authors describe clinical implications only after describing the quality of evidence and the balance of benefits and harms.

\section{Conclusions}

The Cochrane reviews of paediatric dentistry and oral health were of high quality. They provided strong evidence that topical fluoride treatments and sealants are effective for children and adolescents and thus should be implemented in practice. However, a substantial number of reviews yielded inconclusive findings.

\section{Additional files}

Additional file 1: Table S1. Characteristics of included studies.

Additional file 2: Table S2. Characteristics of review comparisons of primary outcomes.

Additional file 3: Table S3. Assessment of implications for practice from included studies.

\section{Competing interests}

The authors declare that they have no competing interests.

\section{Authors' contributions}

VSF drafted the manuscript. HFC and FC participated in the design of the study. All authors conceived of the study, read and approved the final manuscript.

\section{Acknowledgments}

We thank Laura Smales (BioMedEditing, Toronto, Canada) for editing the manuscript.

\section{Author details}

${ }^{1}$ Institut National de la Santé et de la Recherche Médicale, UMR S 872 Equipe 22, Centre de Recherche des Cordeliers, Paris, France. ${ }^{2}$ Assistance Publique-Hôpitaux de Paris, Hôpital Bretonneau, Service d'Odontologie, Paris, France. ${ }^{3}$ Université Paris Descartes - Sorbonne Paris Cité, Faculté de Chirurgie Dentaire, Unité de Recherches Biomatériaux Innovants et Interface EA4462, 1 rue Maurice Arnoux, 92120 Montrouge, France. ${ }^{4}$ Assistance Publique-Hôpitaux de Paris, Hôpital Charles Foix, Service d'Odontologie, Ivry-sur-Seine, France.

Received: 19 December 2013 Accepted: 31 March 2014 Published: 9 April 2014

\section{References}

1. Higgins J, Green S: Cochrane Handbook for Systematic Reviews of Interventions 5.1.0 [updated March 2011]. The Cochrane Collaboration; 2011. Available from: www.cochrane-handbook.org.

2. Moher D, Jadad AR, Nichol G, Penman M, Tugwell P, Walsh S: Assessing the quality of randomized controlled trials: an annotated bibliography of scales and checklists. Control Clin Trials 1995, 16(1):62-73.

3. Mulrow CD: Rationale for systematic reviews. BMJ 1994, 309(6954):597-599.

4. Shea BJ, Grimshaw JM, Wells GA, Boers M, Andersson N, Hamel C, Porter AC, Tugwell P, Moher D, Bouter LM: Development of AMSTAR: a measurement tool to assess the methodological quality of systematic reviews. BMC Med Res Methodol 2007, 7:10.

5. Shea BJ, Hamel C, Wells GA, Bouter LM, Kristjansson E, Grimshaw J, Henry DA, Boers M: AMSTAR is a reliable and valid measurement tool to assess the methodological quality of systematic reviews. J Clin Epidemio/ 2009, 62(10):1013-1020.

6. Liberati A, Altman DG, Tetzlaff J, Mulrow C, Gotzsche PC, loannidis JP, Clarke M, Devereaux PJ, Kleijnen J, Moher D: The PRISMA statement for reporting systematic reviews and meta-analyses of studies that evaluate health care interventions: explanation and elaboration. PLoS Med 2009, 6(7):e1000100.

7. Garner S, Docherty M, Somner J, Sharma T, Choudhury M, Clarke M, Littlejohns P: Reducing ineffective practice: challenges in identifying low-value health care using Cochrane systematic reviews. J Health Serv Res Policy 2013, 18(1):6-12.

8. Clarke M, Clarke T, Clarke L: Cochrane systematic reviews as a source of information for practice and trials. Trials 2011, 12(Suppl 1):A49.

9. Ahovuo-Saloranta A, Forss H, Walsh T, Hiiri A, Nordblad A, Makela M, Worthington $\mathrm{HV}$ : Sealants for preventing dental decay in the permanent teeth. Cochrane Database Syst Rev 2013, 3, CD001830.

10. Al-Harasi S, Ashley PF, Moles DR, Parekh S, Walters V: Hypnosis for children undergoing dental treatment. Cochrane Database Syst Rev 2010, 8, CD007154.

11. Ashley PF, Parekh S, Moles DR, Anand P, Behbehani A: Preoperative analgesics for additional pain relief in children and adolescents having dental treatment. Cochrane Database Syst Rev 2012, 9, CD008392.

12. Ashley PF, Williams CE, Moles DR, Parry J: Sedation versus general anaesthesia for provision of dental treatment in under 18 year olds. Cochrane Database Syst Rev 2012, 11, CD006334.

13. Beirne $\mathrm{P}$, Clarkson JE, Worthington HV: Recall intervals for oral health in primary care patients. Cochrane Database Syst Rev 2007, 4, CD004346.

14. Belmonte FM, Macedo CR, Day PF, Saconato H, Fernandes Moca Trevisani V: Interventions for treating traumatised permanent front teeth: luxated (dislodged) teeth. Cochrane Database Syst Rev 2013, 4, CD006203.

15. Benson PE, Parkin N, Millett DT, Dyer FE, Vine S, Shah A: Fluorides for the prevention of white spots on teeth during fixed brace treatment. Cochrane Database Syst Rev 2004, 3, CD003809.

16. Bessell A, Hooper L, Shaw WC, Reilly S, Reid J, Glenny AM: Feeding interventions for growth and development in infants with cleft lip, cleft palate or cleft lip and palate. Cochrane Database Syst Rev 2011, 2, CD003315.

17. Bonner BC, Clarkson JE, Dobbyn L, Khanna S: Slow-release fluoride devices for the control of dental decay. Cochrane Database Syst Rev 2006, 4, CD005101.

18. Carvalho FR, Lentini-Oliveira D, Machado MA, Prado GF, Prado LB, Saconato $\mathrm{H}$ : Oral appliances and functional orthopaedic appliances for obstructive sleep apnoea in children. Cochrane Database Syst Rev 2007, 2, CD005520.

19. Cooper AM, O'Malley LA, Elison SN, Armstrong R, Burnside G, Adair P, Dugdill $L$, Pine C: Primary school-based behavioural interventions for preventing caries. Cochrane Database Syst Rev 2013, 5, CD009378.

20. Dashash M, Yeung CA, Jamous I, Blinkhorn A: Interventions for the restorative care of amelogenesis imperfecta in children and adolescents. Cochrane Database Syst Rev 2013, 6, CD007157

21. Guo J, Li C, Zhang Q, Wu G, Deacon SA, Chen J, Hu H, Zou S, Ye Q: Secondary bone grafting for alveolar cleft in children with cleft lip or cleft lip and palate. Cochrane Database Syst Rev 2011, 6, CD008050.

22. Harrison JE, O'Brien KD, Worthington HV: Orthodontic treatment for prominent upper front teeth in children. Cochrane Database Syst Rev 2007, 3, CD003452.

23. Hiiri A, Ahovuo-Saloranta A, Nordblad A, Makela M: Pit and fissure sealants versus fluoride varnishes for preventing dental decay in children and adolescents. Cochrane Database Syst Rev 2010, 3, CD003067.

24. Innes NP, Ricketts DN, Evans DJ: Preformed metal crowns for decayed primary molar teeth. Cochrane Database Syst Rev 2007, 1, CD005512.

25. Lentini-Oliveira D, Carvalho FR, Qingsong Y, Junjie L, Saconato H, Machado MA Prado LB, Prado GF: Orthodontic and orthopaedic treatment for anterior open bite in children. Cochrane Database Syst Rev 2007, 2, CD005515.

26. Lourenco-Matharu L, Ashley PF, Furness S: Sedation of children undergoing dental treatment. Cochrane Database Syst Rev 2012, 3, CD003877.

27. Marinho VC, Higgins JP, Logan S, Sheiham A: Fluoride gels for preventing dental caries in children and adolescents. Cochrane Database Syst Rev 2002, 2, CD002280.

28. Marinho VC, Higgins JP, Logan S, Sheiham A: Topical fluoride (toothpastes, mouthrinses, gels or varnishes) for preventing dental caries in children and adolescents. Cochrane Database Syst Rev 2003, 4, CD002782. 
29. Marinho VC, Higgins JP, Logan S, Sheiham A: Fluoride mouthrinses for preventing dental caries in children and adolescents. Cochrane Database Syst Rev 2003, 3, CD002284.

30. Marinho VC, Higgins JP, Sheiham A, Logan S: Fluoride toothpastes for preventing dental caries in children and adolescents. Cochrane Database Syst Rev 2003, 1, CD002278.

31. Marinho VC, Higgins JP, Sheiham A, Logan S: Combinations of topical fluoride (toothpastes, mouthrinses, gels, varnishes) versus single topical fluoride for preventing dental caries in children and adolescents. Cochrane Database Syst Rev 2004, 1, CD002781.

32. Marinho VC, Higgins JP, Sheiham A, Logan S: One topical fluoride (toothpastes, or mouthrinses, or gels, or varnishes) versus another for preventing dental caries in children and adolescents. Cochrane Database Syst Rev 2004, 1, CD002780.

33. Marinho VC, Worthington HV, Walsh T, Clarkson JE: Fluoride varnishes for preventing dental caries in children and adolescents. Cochrane Database Syst Rev 2013, 7, CD002279.

34. Mettes TD, Ghaeminia H, Nienhuijs ME, Perry J, van der Sanden WJ, Plasschaert A: Surgical removal versus retention for the management of asymptomatic impacted wisdom teeth. Cochrane Database Syst Rev 2012 6. CD003879.

35. Millett DT, Cunningham SJ, O'Brien KD, Benson P, Williams A, de Oliveira $C M$ : Orthodontic treatment for deep bite and retroclined upper front teeth in children. Cochrane Database Syst Rev 2006, 4, CD005972.

36. Nadin G, Goel BR, Yeung CA, Glenny AM: Pulp treatment for extensive decay in primary teeth. Cochrane Database Syst Rev 2003, 1, CD003220.

37. Nasser M, Fedorowicz Z, Khoshnevisan MH, Shahiri Tabarestani M: Acyclovir for treating primary herpetic gingivostomatitis. Cochrane Database Syst Rev 2008, 4, CD006700

38. Nasser M, Fedorowicz Z, Newton JT, Nouri M: Interventions for the management of submucous cleft palate. Cochrane Database Syst Rev 2008, 1, CD006703.

39. Parkin N, Benson PE, Thind B, Shah A: Open versus closed surgical exposure of canine teeth that are displaced in the roof of the mouth Cochrane Database Syst Rev 2008, 4, CD006966.

40. Parkin N, Furness S, Shah A, Thind B, Marshman Z, Glenroy G, Dyer F, Benson PE: Extraction of primary (baby) teeth for unerupted palatally displaced permanent canine teeth in children. Cochrane Database Syst Rev 2012, 12, CD004621.

41. Tubert-Jeannin S, Auclair C, Amsallem E, Tramini P, Gerbaud L, Ruffieux C, Schulte AG, Koch MJ, Rege-Walther M, Ismail A: Fluoride supplements (tablets, drops, lozenges or chewing gums) for preventing dental caries in children. Cochrane Database Syst Rev 2011, 12, CD007592.

42. Walsh T, Worthington HV, Glenny AM, Appelbe P, Marinho VC, Shi X: Fluoride toothpastes of different concentrations for preventing dental caries in children and adolescents. Cochrane Database Syst Rev 2010, 1. CD007868.

43. Wong MC, Glenny AM, Tsang BW, Lo EC, Worthington HV, Marinho VC: Topical fluoride as a cause of dental fluorosis in children. Cochrane Database Syst Rev 2010, 1, CD007693.

44. Yengopal V, Harneker SY, Patel N, Siegfried N: Dental fillings for the treatment of caries in the primary dentition. Cochrane Database Syst Rev 2009, 2, CD004483.

45. Yeung CA, Hitchings JL, Macfarlane TV, Threlfall AG, Tickle M, Glenny AM: Fluoridated milk for preventing dental caries. Cochrane Database Syst Rev 2005, 3, CD003876

46. Atkins D, Best D, Briss PA, Eccles M, Falck-Ytter Y, Flottorp S, Guyatt GH, Harbour RT, Haugh MC, Henry D, Hill S, Jaeschke R, Leng G, Liberati A, Magrini N, Mason J, Middleton P, Mrukowicz J, O'Connell D, Oxman AD, Phillips B, Schünemann HJ, Edejer T, Varonen H, Vist GE, Williams JW Jr, Zaza S, GRADE Working Group: Grading quality of evidence and strength of recommendations. BMJ 2004, 328(7454):1490.

47. Egger M, Davey Smith G, Schneider M, Minder C: Bias in meta-analysis detected by a simple, graphical test. BMJ 1997, 315(7109):629-634.

48. Oral health in America: a report of the Surgeon General. J Calif Dent Assoc 2000, 28(9):685-695.

49. Goldberg $M$ : In vitro and in vivo studies on the toxicity of dental resin components: a review. Clin Oral Investig 2008, 12(1):1-8.

50. Koral SM: Mercury from dental amalgam: exposure and risk assessment. Compend Contin Educ Dent 2013, 34(2):138-140. 142, 144 passim.
51. Davey J, Turner RM, Clarke MJ, Higgins JP: Characteristics of meta-analyses and their component studies in the Cochrane Database of Systematic Reviews: a cross-sectional, descriptive analysis. BMC Med Res Methodol 2011, 11:160.

52. Clarke M: Standardising outcomes for clinical trials and systematic reviews. Trials 2007, 8:39.

53. Williamson P, Clarke M: The COMET (Core Outcome Measures in Effectiveness Trials) initiative: its role in improving cochrane reviews. Cochrane Database Syst Rev 2012, 5, ED000041.

54. Furukawa TA, Watanabe N, Omori IM, Montori VM, Guyatt GH: Association between unreported outcomes and effect size estimates in Cochrane meta-analyses. JAMA 2007, 297(5):468-470.

55. Tugwell $P$, Boers M, Brooks P, Simon L, Strand V, Idzerda L: OMERACT: an international initiative to improve outcome measurement in rheumatology. Trials 2007, 8:38.

56. Williamson P, Altman D, Blazeby J, Clarke M, Gargon E: Driving up the quality and relevance of research through the use of agreed core outcomes. J Health Serv Res Policy 2012, 17(1):1-2.

57. Carr A, Wolfaardt J, Garrett N: Capturing patient benefits of treatment. Int J Oral Maxillofac Implants 2011, 26(Suppl):85-92. discussion 101-102.

58. Faggion CM Jr, Listl S, Tu YK: Assessment of endpoints in studies on peri-implantitis treatment-a systematic review. J Dent 2010, 38(6):443-450

59. Needleman I, Chin S, O'Brien T, Petrie A, Donos N: Systematic review of outcome measurements and reference group(s) to evaluate and compare implant success and failure. J Clin Periodontol 2012, 39(Suppl 12):122-132.

60. Papaspyridakos P, Chen CJ, Singh M, Weber HP, Gallucci GO: Success criteria in implant dentistry: a systematic review. J Dent Res 2012, 91(3):242-248.

61. Smail-Faugeron V, Fron Chabouis H, Durieux P, Attal JP, Muller-Bolla M Courson F: Development of a core set of outcomes for randomized controlled trials with multiple outcomes-example of pulp treatments of primary teeth for extensive decay in children. PLoS One 2013, 8(1):e51908.

62. Chalmers I: Well informed uncertainties about the effects of treatments. BMJ 2004, 328(7438):475-476.

63. Chalmers | Sr: Systematic reviews and uncertainties about the effects of treatments. Cochrane Database Syst Rev 2011, 2011, ED000004.

64. Fleming PS, Seehra J, Polychronopoulou A, Fedorowicz Z, Pandis N: Cochrane and non-Cochrane systematic reviews in leading orthodontic journals: a quality paradigm? Eur J Orthod 2013, 35(2):244-248.

65. Fleming PS, Seehra J, Polychronopoulou A, Fedorowicz Z, Pandis N: A PRISMA assessment of the reporting quality of systematic reviews in orthodontics. Angle Orthod 2013, 83(1):158-163.

66. Sequeira-Byron P, Fedorowicz Z, Jagannath VA, Sharif MO: An AMSTAR assessment of the methodological quality of systematic reviews of oral healthcare interventions published in the Journal of Applied Oral Science (JAOS). J App/ Oral Sci 2011, 19(5):440-447.

67. ADA. Center for Evidence-Based Dentistry. Available: http://www.cdc.gov/ nchs/nhanes.htm.

doi:10.1186/1472-6831-14-35

Cite this article as: Smaïl-Faugeron et al:: Methodological quality and implications for practice of systematic Cochrane reviews in pediatric oral health: a critical assessment. BMC Oral Health 2014 14:35.

\section{Submit your next manuscript to BioMed Central and take full advantage of:}

- Convenient online submission

- Thorough peer review

- No space constraints or color figure charges

- Immediate publication on acceptance

- Inclusion in PubMed, CAS, Scopus and Google Scholar

- Research which is freely available for redistribution 